\title{
Daniel Ruge: the first neurosurgeon to serve as physician to the president
}

\author{
A. Karim Ahmed, BS, ${ }^{1}$ Eduardo Martinez-del-Campo, MD, ${ }^{2}$ and Nicholas Theodore, MD ${ }^{1}$ \\ 'Department of Neurosurgery, The Johns Hopkins School of Medicine, Baltimore, Maryland; and 2Department of Neurosurgery, \\ Medical College of Wisconsin, Milwaukee, Wisconsin
}

\begin{abstract}
The role of chief White House physician has traditionally been held by an individual with a background in a broad medical field, such as emergency medicine, family medicine, or internal medicine. Dr. Daniel Ruge, who served as the director of the Spinal Cord Injury Service for the Veterans Administration and was appointed during President Ronald Reagan's first term, was the first neurosurgeon to become the chief White House physician. Aside from being the first neurosurgeon to serve in this capacity, Dr. Ruge also stands apart from others who have held this esteemed position because of how he handled Reagan's care after an attempt was made on the then-president's life. Instead of calling upon leading medical authorities of the time to care for the president, Dr. Ruge instead decided that Reagan should be treated as any trauma patient would be treated. Dr. Ruge's actions after the assassination attempt on President Reagan resulted in the rapid, smooth recovery of the then-president. Daniel Ruge's background, his high-profile roles and heavy responsibilities, and his critical decision-making are characteristics that make his role in the history of medicine and of neurosurgery unique. https://thejns.org/doi/abs/10.3171/2018.4.JNS172384
\end{abstract}

KEYWORDS Daniel Ruge; Ronald Reagan; physician to the president; history

$\mathrm{T}$ HE physician to the president, also known as the chief White House physician, directs the White House Medical Unit, which is an entity of the White House Military Office. As such, many individuals who serve as physician to the president are active-duty military members. Traditionally, the role of chief White House physician has been filled by an individual whose background is in a broad medical field, such as emergency medicine, family medicine, or internal medicine., ${ }^{1,934}$ Dr. Daniel Ruge, who served under President Ronald Reagan, was the first physician to the president with a neurosurgical background. Sixty-three years old at the time of his appointment, he was also the oldest physician to have held this important position.

\section{Education and Early Years}

Daniel Ruge was born in Murdock, Nebraska, on May 13, 1917, and was raised on a farm in Nebraska. After completing a semester at the University of Nebraska, Ruge transferred to North Central College in Naperville, Illinois. He went on to graduate from medical school at Northwestern University in 1945. ${ }^{1,32}$
In a 1983 interview for the American Association of Neurological Surgeons archives, ${ }^{34}$ Ruge attributed his interest in neurosurgery largely to Dr. Loyal Davis, the first neurosurgeon in Chicago and the former chief of surgery at Northwestern University School of Medicine. Davis was stepfather to Nancy Davis Reagan and father-in-law to President Ronald Reagan. Some of Dr. Davis' most notable contributions included developing an aviation helmet that helped protect military pilots from shrapnel and refining the treatment for frostbite injuries. ${ }^{6}$

As a medical student on Dr. Davis' surgical service, Dr. Ruge became interested in Dr. Davis' trigeminal neuralgia cases - "I think also I was quite interested in him as a person," Dr. Ruge later said, reflecting on his mentor. ${ }^{34}$ In his senior year of medical school, Dr. Ruge clerked for Dr. Davis and went on to train in neurosurgery under his guidance, ${ }^{32,34}$ completing his training on December 31, 1951. As a resident, Dr. Ruge rotated at the Edward Hines Jr. Veterans Administration (VA) Hospital, located near Chicago. Hines VA was one of the five original VA hospitals to care for World War II veterans who had sustained spinal cord injuries. As Ruge recalled, “... at any

ABBREVIATIONS VA $=$ Veterans Administration 
given time, there were over 300 patients with spinal cord injury at Hines [VA Hospital]." ${ }^{34}$ Patients who sustained spinal cord injuries in World War II had more favorable survival than those who had experienced spinal cord injury in World War I, due to improved surgical techniques, better treatment for shock, and more effective antibiotic use. During World War I, 400 American soldiers were removed from the battlefield with an acute spinal cord injury and $90 \%$ died within 1 year of injury. ${ }^{22}$ In contrast, 2000 American soldiers who had sustained spinal cord injury were admitted to military and VA hospitals by the end of World War II, ${ }^{12}$ and $75 \%$ of American soldiers rendered paraplegic during World War II were still alive 20 years after the war. ${ }^{31}$ As one of the few hospitals serving these patients, the Hines VA saw a large volume of patients with acute and chronic spinal cord injuries. ${ }^{12,22}$

\section{Neurosurgical Career}

After completing his training, Dr. Ruge practiced in close association with Dr. Davis for more than 20 years, as a faculty member at Northwestern Memorial Hospital. In addition, Dr. Ruge had an appointment at the VA hospital beginning in 1952. Throughout his neurosurgical career, his most notable work was in the field of spinal cord injury. He authored a textbook on spinal cord injury ${ }^{30}$ and published numerous manuscripts describing myriad spinal disorders. ${ }^{8,11,15,21}$ Dr. Ruge was the senior author on the first case report describing symptomatic vertebral artery occlusion due to a dumbbell-shaped neurofibroma in the cervical spine. ${ }^{11}$

In 1961, Dr. Ruge and colleagues also published a series of 23 patients diagnosed with metastatic epidural spinal tumors. ${ }^{15}$ Ruge's group at Northwestern described the mean postoperative survival time for lung carcinoma (7 months), Hodgkin and non-Hodgkin lymphoma (13 months), prostate carcinoma (11 months), carcinoma of the kidney and bladder (3 months), and carcinoma of unknown primary origin (7 months). Postoperative neurological improvement was observed in 50\% of patients, and in $100 \%$ of patients with Hodgkin and non-Hodgkin lymphoma of the spine. Prompt decompression and the use of adjuvant therapy were probably responsible for the neurological improvement and survival in patients with epidural lymphoma. Ruge's results-namely, improved survival and neurological recovery-are consistent with one of the landmark studies of the time, by D. M. Perese, published in Cancer $^{26}$ Perese also observed high rates of neurological recovery for patients with lymphoma and noted that "... each of the patients who recovered from paraplegia after operation was also treated with radiation and in some instances with chemotherapeutic agents," which was similar to the recommendations made by Ruge. ${ }^{15}$

Published in JAMA Neurology in 1978 (formerly Archives of Neurology), Ruge's seminal work at the VA involved the study of patients with traumatic spinal cord injury over a 10 -year period (1955-1965). ${ }^{21}$ His dedicated study ultimately facilitated calculable timetable survival rates at various intervals after injury. For quadriplegic and paraplegic patients who survived more than 3 months after injury, 10 -year survival was $80 \%$ and $86 \%$, respective- ly. Furthermore, Ruge identified age at the time of spinal cord injury, level of the lesion, and extent of paralysis as significant factors that affect survival in patients with traumatic spinal cord injury.

After a successful career in Chicago, Dr. Ruge moved to Washington, DC, in 1976 to become the deputy director of spinal cord injury services for the VA, and became the director of the same just 4 years later. ${ }^{1,32,34}$

\section{The White House}

As his close friend, colleague, and mentor, Loyal Davis first approached Daniel Ruge about becoming the White House physician in 1976, when Ronald Reagan first ran for president. Ronald Reagan did not win that race, but when he won the 1980 presidential election, Dr. Davis approached Ruge once again. Initially hesitant to accept, Ruge later recalled, "I thought that the position should be filled by a younger person, preferably someone in Family Practice or Internal Medicine." ${ }^{34}$ However, 2 days later he accepted the offer and became the oldest chief White House physician and the first neurosurgeon to serve in that capacity (Figs. 1 and 2). When asked about his unique and incredible responsibility, Dr. Ruge stated, "I don't look upon myself as the man who should be treating [President Reagan] if he became ill; I think that it is my responsibility to see that he gets good care should he become ill." 34

Dr. Ruge did not frequently appear in the public eye and often spent state dinners in his office completing crossword puzzles. He remarked that the role was "vastly overrated, boring, not medically challenging-and not one of the glamour spots in the White House." ${ }^{27}$ When Ronald Reagan began his second term in 1985, Ruge declined a second term, retired, and moved to Denver with his wife. He was succeeded as White House physician by urologist T. Burton Smith. Dr. Ruge died in 2005, at the age of 88 .

\section{Attempted Assassination of President Reagan}

President Reagan was scheduled to address the Building and Construction Trades Department of the American Federation of Labor and Congress of Industrial Organizations on March 30, 1981, in the Washington Hilton Hotel. ${ }^{27,33}$ John W. Hinckley Jr., armed with a 0.22-caliber pistol and experiencing erotomania, fired 6 shots at President Reagan as he left the hotel. The shots were fired in 1.7 seconds and hit multiple individuals in Reagan's entourage. The shots included one in the right chest of Secret Service agent Tim McCarthy, one in the back of DC police officer Thomas Delahanty, and one in the head of Press Secretary Jim Brady. The sixth shot ricocheted off Reagan's limousine and hit Reagan in the chest. ${ }^{33}$

Dr. Ruge made a habit of memorizing the President's attire every morning in preparation for such a situation. After confirming that none of the wounded outside the hotel were wearing the president's blue suit, Ruge followed Reagan in the limousine behind the president's limousine. President Reagan complained of not being able to breathe and speculated that it was due to Secret Service agent Jerry Parr landing on top of him when the shots were 
fired. Upon initial inspection, there was no visible blood in Reagan's mouth or nose, so Parr had initially ordered the driver to take the car back to the White House. Soon thereafter, Reagan wiped his mouth and demonstrated a copious amount of frothy blood, which Parr suspected was from a lung injury. Parr then had the car rerouted to the Emergency Department at George Washington University Hospital.

Upon receiving the call from the president's motorcade, the assistant nurse in charge of the unit, Judith Whinerey, called the chief of each department and specialty within the hospital in order to ensure that the most experienced physicians would be available to treat the president. Once Dr. Ruge arrived, however, he was adamant that President Reagan be treated like any other patient would be treated. Following the standard emergency department procedure of "strip, insert IVs, and start fluids," a percutaneously inserted central catheter was inserted in the right arm, and a peripheral line was inserted in the left. ${ }^{33}$ Still unsure of the origin of the bleeding, Ruge thought that the President had sustained a myocardial infarction. Dr. G. Wesley Price, a surgical resident, entered the trauma bay and was notified by Whinerey that he was in charge of the case. Price inspected the president and, upon hearing no breath sounds on the left side, requested that the President be rolled over. This revealed a posterior gunshot entrance wound under the left axilla.

Dr. Ruge did not summon prestigious specialty physicians from other institutions to care for the presidentrather, he advised the emergency and trauma teams to care for President Reagan as they would care for any trauma patient. Following auscultation and percussion of the president's chest, Dr. Price diagnosed a hemothorax, and Dr. Joseph Giordano, the head trauma surgeon, inserted a chest tube and drained $1300 \mathrm{ml}$ of blood. Dr. Giordano pioneered the development of specialized trauma teams and protocols at George Washington University Hospital, and completed additional training from Dr. R. Adams Cowley at the Maryland Institute for Emergency Medical Services (now known as University of Maryland R. Adams Cowley Shock Trauma Center). Giordano later mandated that all George Washington surgical residents complete a 3-month rotation at Shock Trauma. . $5,33^{-3}$

Due to the dark color of deoxygenated blood returning from the president's chest tube, Dr. Ben Aaron, a cardiothoracic surgeon and former Navy surgeon with 22 years' experience, suspected injury to the pulmonary tree and decided to operate. He asked Dr. Ruge, "How important is it that I get the bullet out?" Ruge responded, "What's important is the President survive." 25

Dr. Aaron was able to remove the bullet from the lung parenchyma, ${ }^{25}$ and although he considered removing the lower lobe of the left lung (which had sustained the most damage and could be a nidus for infection), he ultimately decided to leave it in place. ${ }^{33}$ The operation lasted just over 3 hours, and Dr. Aaron placed 2 chest tubes upon closure. Since he had arrived at the hospital, the president had lost roughly $3.5 \mathrm{~L}$ of blood, had 8 units of packed red blood cells and $5.7 \mathrm{~L}$ of fluids infused, and was placed on 40\%-50\% oxygen.

Dr. Ruge intentionally remained removed from the

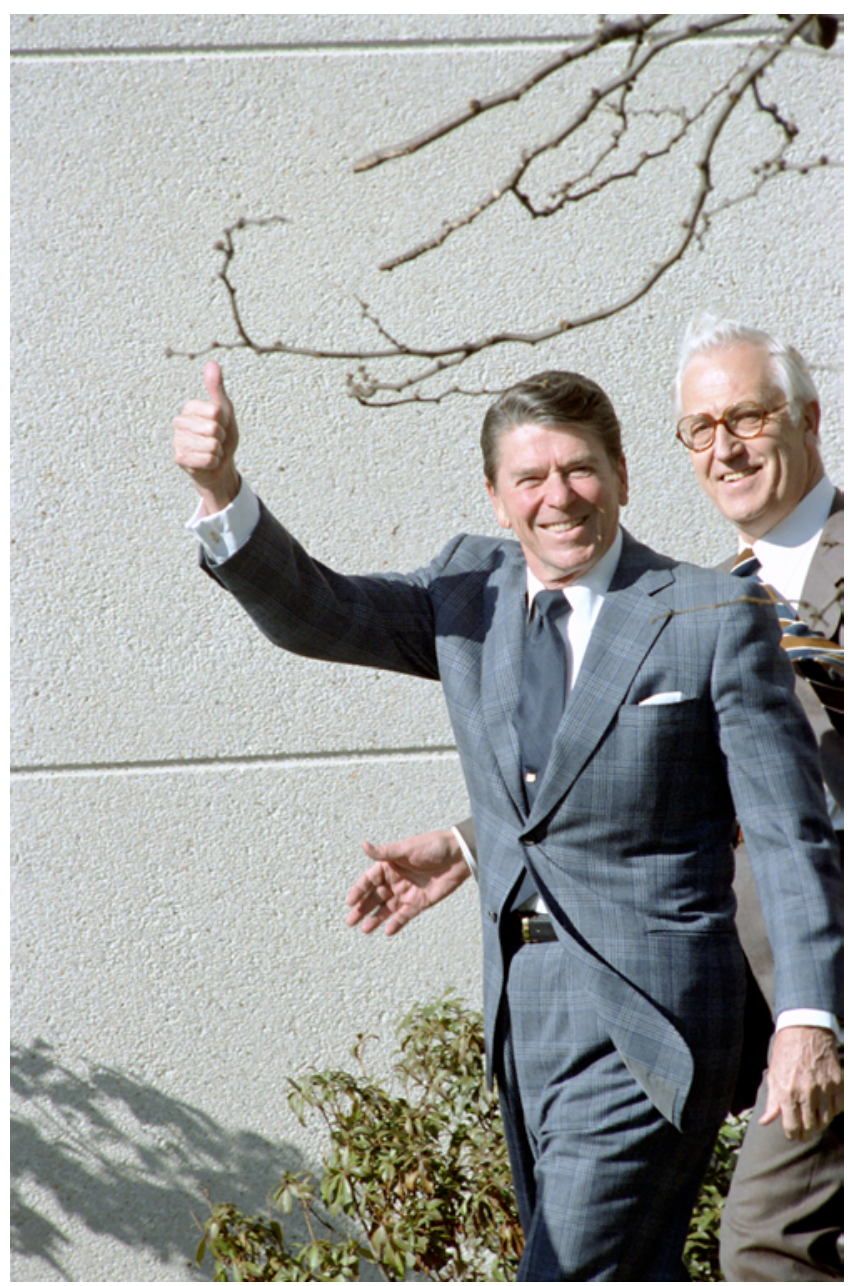

FIG. 1. Dr. Ruge with President Ronald Reagan. Courtesy of the Ronald Reagan Presidential Library (photograph is in the public domain). Figure is available in color online only.

trauma protocol in an effort to minimize any interruptions in care-so removed, in fact, that when a surgeon asked a nearby Secret Service agent to identify anyone he did not recognize, the surgeon pointed to Dr. Ruge and said, "I don't know that guy." ${ }^{5}$ Tom Ruge, Dr. Ruge's son, later recalled, "My dad was very clear that a big part of his job was to make sure that everything moved according to normal procedures.... He told me that when he went into the emergency room, he asked the staff, 'If this was anyone else coming in with a gunshot wound, what is the first thing you'd do?' They replied, and he said, 'Then that is what we are going to do." "'33 In this moment of great urgency, Dr. Ruge demonstrated confidence in the on-call trauma team at the hospital, and made a wise decision not to interrupt the normal standard of care at that institution. Dr. Ruge recognized that to outsource or to intervene in the care of President Reagan in that dire moment would only impede the excellent care he would otherwise receive, and deferred the provision of care to more senior trauma experts, as would be expected in such a case. ${ }^{1,25,27,32-34}$ President Reagan was discharged from the hospital on April 11, 1981. 


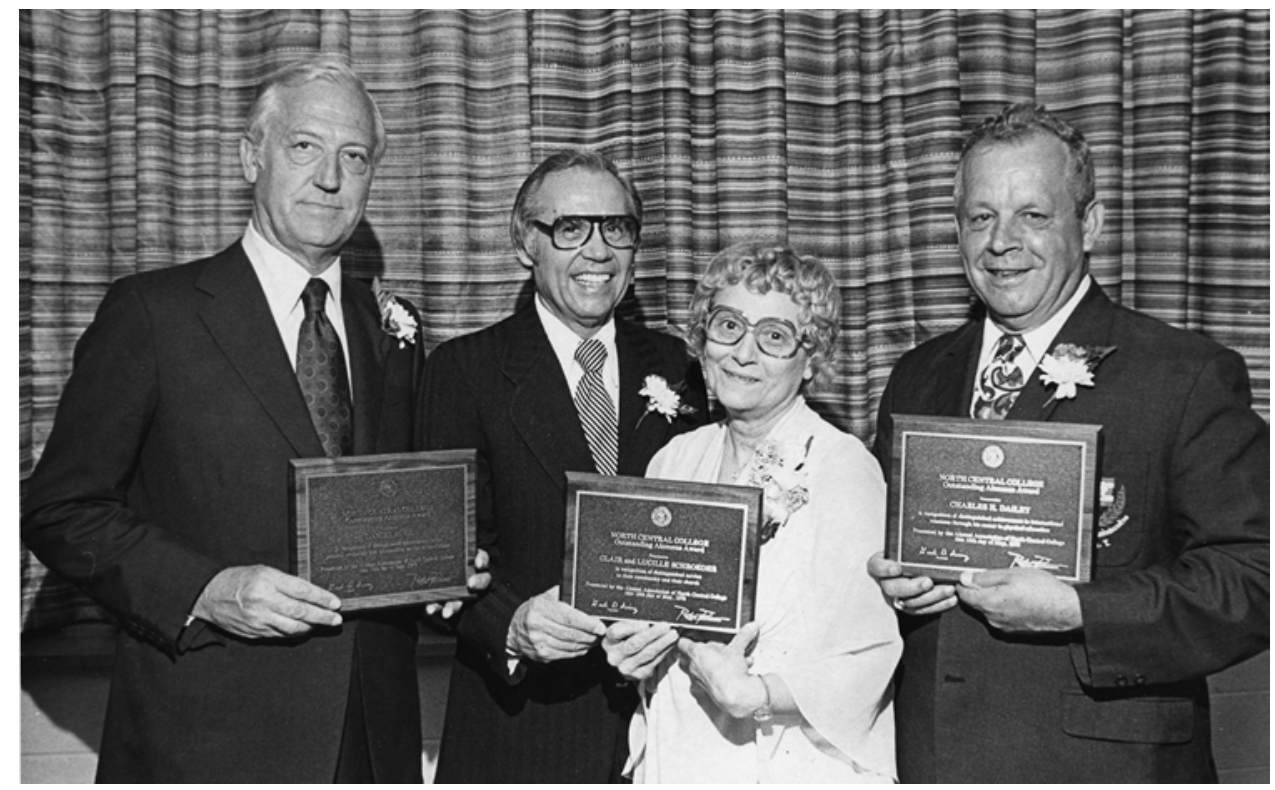

FIG. 2. Dr. Ruge in 1978 (far left), receiving the Outstanding Alumnus Award from North Central College, his alma mater. Courtesy of North Central College, Naperville, Illinois.

\section{Transfer of Power}

Section 3 of the 25th Amendment of the US Constitution outlines the transfer of executive power to the vice president in the event that the president is unable perform the duties of office, as would be the case during surgery. ${ }^{1}$ Despite carrying a copy of this amendment in his bag, Dr. Ruge elected not to invoke the transfer of power to thenVice President George H. W. Bush after the attempt on President Reagan's life. ${ }^{1,27}$ Dr. Ruge later indicated that he regretted that decision, particularly because President Reagan underwent general anesthesia before surgery. 1,9,25,33,34 Due to concerns regarding political allegiance and secure voice communication, Presidential Counselor Edwin Meese III and Chief of Staff James A. Baker also decided against transferring power to Vice President Bush, who was traveling by plane at the time of the assassination attempt.

\section{Physician to the President}

The physician to the president, or the chief White House physician, directs the White House Medical Unit and orchestrates care for the president, the vice president, and White House personnel. The first personal physician to a US president was named Samuel Bard, and he served then-President George Washington. Bard is best known for incising and draining a bacterial abscess on the president's left thigh. The first official physician to the president, however, was Dr. Presley Rixey, who assumed the role in 1901, and served Presidents William McKinley and Theodore Roosevelt (Table 1). ${ }^{9}$ Most White House physicians have had military backgrounds, have received nonsurgical specialty training, and have served multiple presidents, often serving as assistant White House physician before assuming the chief role. The political involvement of the White House physician has varied over the years.
Cary Grayson, who served as White House physician to Woodrow Wilson, wrote a letter to previous White House physician Presley Rixey stating, “... The President gives me a lot of things of a personal nature to attend to, and as a personal aide, I have to be on hand all the time."

Cary Grayson was known for summoning top medical professionals for any indication for President Wilson. When President Wilson developed a urinary tract obstruction, Grayson called upon Dr. Hugh Young, a urologist from Johns Hopkins University, considered to be the " $\mathrm{Fa}$ ther of Modern Urology," as well as Charles Mayo, the founder of the Mayo Clinic. Grayson was also known to conceal the numerous strokes President Wilson had over the years, including a massive one in 1919. To care for the president during these times, Dr. Grayson enlisted the help of Dr. William Keen, who performed the first brain tumor surgery in the country, and Dr. George de Schweinitz, who was the president of the International Congress of Ophthalmology.9, ${ }^{9,2}$ In a letter to his wife, Dr. Grayson remarked, "I am hurrying off to Philadelphia with him at six o'clock tomorrow morning to consult an eye specialist. We are going by motor. I think we can make the trip less noticeable in this way.... [T] he papers will read something like this: "The president made his annual visit to the oculist etc., etc."'7

Interestingly, President Warren G. Harding's chosen White House physician was a homeopath named Charles Sawyer. President Harding appointed Sawyer as a Brigadier General in the US Army and chairman of the Federal Hospitalization Board. Given the magnitude of the role, disputes regarding care have been common among the chief White House physician and assistant or consulting physicians. Sawyer stirred up controversy among medical professionals when he managed President Harding's congestive heart failure by administering purgatives, laxatives, and arsenic, and injecting heart stimulants. ${ }^{19}$ In 
TABLE 1. White House physicians, 1901-present

\begin{tabular}{|c|c|c|c|}
\hline Physician & Specialty* $^{*}$ & President(s) Served & Years Served \\
\hline Presley Rixey & NA & William McKinley, Theodore Roosevelt & $1901-1909$ \\
\hline Matthew A. Delaney & NA & William Howard Taft & $1909-1913$ \\
\hline Cary Travers Grayson & NA & Woodrow Wilson & $1913-1921$ \\
\hline Charles E. Sawyer & Homeopathic medicine & Warren G. Harding & $1921-1923$ \\
\hline James Francis Coupal & NA & Calvin Coolidge & $1923-1929$ \\
\hline Joel Thompson Boone & NA & Herbert Hoover & $1929-1933$ \\
\hline Ross T. Mclntire & NA & Franklin D. Roosevelt & $1933-1945$ \\
\hline Wallace H. Graham & NA & Harry S. Truman & $1945-1953$ \\
\hline Howard McCrum Snyder & NA & Dwight D. Eisenhower & $1953-1961$ \\
\hline Janet G. Travell & Clinical pharmacology \& cardiology & John F. Kennedy & $1961-1963$ \\
\hline George G. Burkley & Cardiology & Lyndon B. Johnson & 1963-1969 \\
\hline Walter R. Tkach & Aerospace \& aviation medicine & Richard Nixon & 1969-1974 \\
\hline William M. Lukash & Gastroenterology & Gerald Ford, Jimmy Carter & 1974-1981 \\
\hline Daniel A. Ruge & Neurosurgery & Ronald Reagan & $1981-1985$ \\
\hline T. Burton Smith & Urology & Ronald Reagan & $1985-1987$ \\
\hline John E. Hutton & Vascular surgery & Ronald Reagan & $1987-1989$ \\
\hline Burton J. Lee III & Oncology & George H. W. Bush & 1989-1993 \\
\hline Eleanor Mariano & Internal medicine & Bill Clinton & $1993-2001$ \\
\hline Richard J. Tubb & Family medicine & George W. Bush & $2002-2009$ \\
\hline Jeffrey Kuhlman & Family medicine & Barack Obama & $2009-2013$ \\
\hline Ronny Jackson & Emergency medicine & Barack Obama, Donald Trump & 2013-2018 \\
\hline Sean Conley & Emergency medicine & Donald Trump & 2018-present \\
\hline
\end{tabular}

similar fashion, the White House physician under John F. Kennedy treated his chronic back pain with hundreds of trigger-point procaine injections, and suggested a lifted heel and rocking chair. ${ }^{23}$

Like President Wilson's White House physician, the doctor entrusted with the care of President Eisenhower made a habit of summoning experts in any given field when needed for the president. When Eisenhower had a small-bowel obstruction, his surgical team included Leonard Heaton, Surgeon General of the US Army; Isidor Ravdin, chairman of surgery at the University of Pennsylvania; Brian Blades, chief of surgery at George Washington University; and John Lyons, the top private practice surgeon in Washington, DC. In contrast to the norm for many other presidents, however, reports on Eisenhower's health and surgeries were disseminated to the public as the reporting of presidential health matters became more routine. ${ }^{3,13}$

Ronald Reagan was the first and only president to have selected a neurosurgeon as the White House physician, and while in office, Reagan continued to exclusively appoint surgeons for this role. President Reagan's White House physicians were entrusted with the care of not only the president, but also of his family: Dr. Ruge's successor, a urologist named T. Burton Smith, performed a transurethral prostatectomy on the president; ${ }^{4}$ meanwhile, Reagan's third appointee to the role (Dr. Hutton, a vascular surgeon) was part of a team that performed a mastectomy on the first lady and another team that removed the president's intestinal polyps. ${ }^{9}$

\section{US Presidents Shot in Office}

Abraham Lincoln was the first US president to sustain a gunshot wound while he held the office of the president. On April 14, 1865, Lincoln was famously shot with a 0.44 -caliber weapon while at the theater. The bullet entered the president's skull at the posterior aspect of the cranium, traveled anteriorly through the left lateral ventricle, and came to rest in the white matter immediately superior to the left corpus striatum, causing bilateral orbital fractures. Lincoln was promptly tended to by a 23 -year-old US Volunteers assistant surgeon, Dr. Charles A. Leale, who had graduated from medical school only days earlier. Upon arrival to Lincoln's theater booth, Leale stated, "His wound is mortal; it is impossible for him to recover."18 Leale was assisted in caring for President Lincoln by a 30-year-old physician named Charles Taft. Drs. Leale and Taft repeatedly probed President Lincoln's head wound to allow blood to escape and to prevent an elevation in intracranial pressure, temporarily relieving the president's respiratory distress. As stated by his physicians, “... As long as bleeding continued, the President's condition remained stable. When the flow stopped, the vital signs weakened.... It would produce signs of increased compression." 18 Considering President Lincoln's dilated left pupil and blood- 
soaked sheets, cerebral herniation and massive hemorrhage were the likely causes of his death the next morning. ${ }^{5,17,18}$

On July 2, 1881, President James A. Garfield was shot twice-once in the right arm and once in the back. The bullet that hit Garfield in his back traversed the L1 vertebra before injuring the president's splenic artery. The splenic artery formed a pseudoaneurysm, which was tamponaded by retroperitoneum. President Garfield was cared for by the best surgeons of the time. At the time, any bullet left in a wound was thought to cause infection and end-stage organ damage, so attempts were made to retrieve the bullet that hit Garfield in the back; however, the wound was probed repeatedly, without success. Alexander Graham Bell even used a prototype metal detector to find it, but was also unsuccessful. President Garfield died on September 19, 1881, due to presumed septicemia-although other reports point to acute cholecystitis and a ruptured splenic artery aneurysm..$^{24,28}$

President William McKinley was shot twice while visiting the Pan-American Exhibit in Buffalo, New York, on September 6, 1901. One bullet struck him in the upper sternum; the other hit the left hypochondrium. President McKinley was rushed to a nearby hospital for surgery, and as he was disrobed on the operating table, one of the bullets fell onto the table. The other bullet was never located. President McKinley died just 8 days later due to pancreatic necrosis. His death led to new legislation that designated the Secret Service responsible for the security of the US president. ${ }^{2,29}$

President Theodore Roosevelt was shot on October 14, 1912, by a 0.38-caliber revolver, at the Gilpatrick Hotel in Milwaukee, Wisconsin. Initially, President Roosevelt did not know he had been hit, exclaiming "He missed me. I'm not hurt a bit." ${ }^{10}$ Once he was in his car, one of President Roosevelt's secretaries noticed a bullet hole in his heavy overcoat. The bullet had passed through a 50-page manuscript in his pocket that had been folded in half, as well as his steel spectacle case, before it entered his chest. After several roentgenograms and multiple professional opinions, the bullet was determined to be trapped in the chest wall, but had not entered the pleural space; therefore, removal was not deemed necessary.

President John F. Kennedy was fatally shot on November 22, 1963, while seated in the back of an uncovered limousine. Within 4 minutes of being hit, the president arrived at the trauma bay of Parkland Memorial Hospital in Dallas, Texas. The president was pronounced dead within 12 minutes of his arrival to the trauma room. ${ }^{14}$ The objective findings by the principal pathologists who performed the president's autopsy were detailed in a 1992 article in the Journal of the American Medical Association. The article states that the president was struck by two bullets: one that entered the base of the neck posteriorly and exited through the throat, and one that entered the posterior occiput, exiting the right side of the cranium - consistent with the fracture patterns observed and with the findings of the widely publicized Warren Commission Report. ${ }^{16}$

\section{Conclusions}

The White House physician has traditionally been a member of the US military, and has historically received training in a nonsurgical medical specialty. Dr. Daniel Ruge stands out in the history of physicians who have filled this role not only because he is the only neurosurgeon to have occupied it, but also because he was a prolific researcher, a talented neurosurgeon, and because he quickly determined the best way to care for President Reagan after the attempt on Reagan's life. His adherence to standard trauma protocols-even allowing trainees to treat the president directly-were unorthodox, but may have been critical to the president's recovery.

\section{References}

1. Altman LK: Daniel Ruge, 88, dies; cared for Reagan after shooting. New York Times. September 6, 2005. (https:// www.nytimes.com/2005/09/06/politics/daniel-ruge-88-diescared-for-reagan-after-shooting.html) [Accessed June 26, 2018]

2. Ashrafian H: President William McKinley (1843-1901): the first reported case of traumatic gunshot pancreatitis. Pancreas 41:980-981, 2012

3. Barr J, Pappas TN: President Eisenhower and his bowel obstruction. Bulletin of the American College of Surgeons. November 1, 2017. (http://bulletin.facs.org/2017/11/presidenteisenhower-and-his-bowel-obstruction) [Accessed June 26, 2018]

4. Beahrs OH: The medical history of President Ronald Reagan. J Am Coll Surg 178:86-96, 1994

5. Beatty R, Newmark JL: A day that changed American history. Circulating Now. April 14, 2015. (https://circulatingnow.nlm.nih.gov/2015/04/14/a-day-that-changed-americanhistory/) [Accessed June 26, 2018]

6. Cannon L: Noted brain surgeon. Washington Post. August 20, 1982. (https://www.washingtonpost.com/archive/ local/1982/08/20/noted-brain-surgeon/d97f6655-8c24-48b1a353-f4a7d4a296b4/?utm_term=.919fe04d6a85) [Accessed June 26, 2018]

7. Chandler MA: A president's illness kept under wraps. Washington Post. February 3, 2007. (http://www.washingtonpost. com/wp-dyn/content/article/2007/02/02/AR2007020201698. html) [Accessed June 26, 2018]

8. Davis RA, Brochner R, Ruge D, Wetzel N: Notes on some unusual causes of spinal cord compression. Q Bull Northwest Univ Med Sch 32:329-337, 1958

9. Deppisch LM: The White House Physician: A History from Washington to George W. Bush. Jefferson, NC: McFarland, 2007

10. Foley WJ: A bullet and a bull moose. JAMA 209:2035-2038, 1969

11. Geissinger JD, Gruner G, Ruge D: Vertebral artery occlusion by a cervical 'hour-glass' neurofibroma. J Neurol Neurosurg Psychiatry 35:899-902, 1972

12. Gregory MF: Sexual Adjustment: A Guide for the Spinal Cord Injured. Bloomington, IL: Accent On Living, 1975

13. Heaton LD, Ravdin IS, Blades B, Whelan TJ: President Eisenhower's operation for regional enteritis: a footnote to history. Ann Surg 159:661-666, 1964

14. Jervis R: Doctor who treated Kennedy relives final moments. USA Today. August 7, 2013. (https://www.usatoday.com/ story/news/nation/2013/08/07/kennedy-assassination-doctorparkland/2609969/) [Accessed June 26, 2018]

15. Larson S, Wetzel N, Brochner R, Ruge D: The surgical treatment of metastatic epidural tumors. Q Bull Northwest Univ Med Sch 35:42-44, 1961

16. Lundberg GD: Closing the case in JAMA on the John F. Kennedy autopsy. JAMA 268:1736-1738, 1992

17. Mackowiak PA: Diagnosing Giants: Solving the Medical 
Mysteries of Thirteen Patients Who Changed the World. New York: Oxford University Press, 2013

18. Mackowiak PA: Would Lincoln have survived if he was shot today? Atlantic. November 29, 2013. (https://www. theatlantic.com/health/archive/2013/11/would-lincoln-havesurvived-if-he-was-shot-today/281680/) [Accessed June 26, 2018]

19. Markel H: The 'strange' death of Warren G. Harding. PBS NewsHour. August 2, 2005. (https://www.pbs.org/newshour/ health/strange-death-warren-harding) [Accessed June 26, 2018]

20. Menger RP, Storey CM, Guthikonda B, Missios S, Nanda A, Cooper JM: Woodrow Wilson's hidden stroke of 1919: the impact of patient-physician confidentiality on United States foreign policy. Neurosurg Focus 39(1):E6, 2015

21. Mesard L, Carmody A, Mannarino E, Ruge D: Survival after spinal cord trauma. A life table analysis. Arch Neurol 35:78-83, 1978

22. Nikas V, Fleischman P, Burton P: Sexual and marital adjustment of World War II spinal cord injured veterans. Paraplegia 28: $164-171,1990$

23. Pait TG, Dowdy JT, John F: John F. Kennedy's back: chronic pain, failed surgeries, and the story of its effects on his life and death. J Neurosurg Spine 27:247-255, 2017

24. Pappas TN, Joharifard S: Did James A. Garfield die of cholecystitis? Revisiting the autopsy of the 20th president of the United States. Am J Surg 206:613-618, 2013

25. Pekkanen J: The saving of the president. Washingtonian. March 10, 2011. (https://www.washingtonian.com/2011/03/10/ the-saving-of-the-president/) [Accessed June 26, 2018]

26. Perese DM: Treatment of metastatic extradural spinal cord tumors; a series of 30 cases. Cancer 11:214-221, 1958

27. Reed C: Daniel Ruge. Ronald Reagan's doctor faced with key decisions over US power. Guardian. September 6, 2005. (https://www.theguardian.com/news/2005/sep/07/ guardianobituaries.usa) [Accessed June 26, 2018]

28. Reyburn R: Clinical history of the case of President James Abram Garfield. JAMA 22:460-464, 1894

29. Rixey PM, Mann MD, Mynter H, Park R, Wasdin E, McBurney C, et al: The official report on the case of President M'Kinley. JAMA 37:1029-1036, 1901
30. Ruge D: Spinal cord injury service in the VA. Surg Neurol 15:406, 1981

31. Schültke E: Spinal cord injury. Encyclopaedia Britannica. March 17, 2016. (https://www.britannica.com/science/spinalcord-injury) [Accessed June 26, 2018]

32. Sherlock B: Dr. Daniel Ruge 1917-2005. White House physician for Reagan. Chicago Tribune. September 4, 2005. (http://articles.chicagotribune.com/2005-09-04/ news/0509040294_1_north-central-college-abdominalaortic-aneurysm-dr-daniel-ruge) [Accessed June 26, 2018]

33. Wilber DQ: Rawhide Down: The Near Assassination of Ronald Reagan. New York: Henry Holt \& Co, 2011

34. Williams PE, Neblett CR: Daniel Ruge, MD interviewed by Phillip E. Williams Jr., MD and Charles R. Neblett, MD [video]. American Association of Neurological Surgeons: Leaders in Neuroscience: An Archives Video-Interview Series. (https://www.youtube.com/watch?v=wqGY2_7wd4o) [Accessed June 26, 2018]

\section{Disclosures}

The authors report no conflict of interest concerning the materials or methods used in this study or the findings specified in this paper.

\section{Author Contributions}

Conception and design: all authors. Acquisition of data: Martinezdel-Campo. Drafting the article: all authors. Critically revising the article: all authors. Reviewed submitted version of manuscript: Theodore, Ahmed. Approved the final version of the manuscript on behalf of all authors: Theodore. Administrative/technical/ material support: Ahmed. Study supervision: Theodore.

\section{Correspondence}

Nicholas Theodore: Johns Hopkins Medical Institutions, Baltimore, MD. theodore@jhmi.edu. 